\title{
Research on the Reform of the Ability-oriented Innovation and Entrepreneurship Education System for the Design Major
}

\author{
Dong Yan $^{1, a}$ \\ ${ }^{1}$ Dalian University Of Science And Technology, Dalian, Liaoning, China
}

\begin{abstract}
The research on the reform of the ability-oriented innovation and entrepreneurship education system is of great significance to promote the quality and entrepreneurship of graduates in product design major of the application-oriented colleges and universities. Aiming to foster students' innovation and entrepreneurship abilities and serve the local economy, the five-in-one education mode integrates with weekly cultivation plan, theoretical teaching, practical teaching, graduation project, and innovation and entrepreneurship program, which is available to deepen the education reform of the product design major, accelerate the application-oriented transformation, and achieve high employment and entrepreneurship rate of graduates.
\end{abstract}

\section{The personnel training system based on innovation and entrepreneurship}

Aiming to cultivate innovation and entrepreneurship abilities, the personnel training system is endowed with an vision of making a transformation design for the fostering of the versatile talents with the abilities of practice, innovation and entrepreneurship in a reform way of application practice, discipline, as well as open and communication. The whole training system includes the re-designs of the training objective to reshape the applied talents in terms of the relevant issues, the curriculum system to modularize of the common basic courses, the teaching faculties to establish a mentor system for the interdisciplinary teachers and experts, the teaching platform to shift the module-based teaching to the one combining the studio-based teaching and project teaching, and the practical platform to further the cooperation between school and enterprise by establishing practice bases in the enterprises. Therefore, it can be improved as a five-in-one education system for practice and promotion.

\section{Five-in-one education system structure}

The five-in-one education system involves five aspectsinter discipline, faculty structure construction, project teaching, further cooperation between school and enterprise, and service for the development of the local economy. The result of the research is of important practical significance for the private application-oriented colleges and universities to boost graduates' high-quality employment and entrepreneurship. With the purposes of training students' innovation and entrepreneurship ability and finally making contributions to the local economy, the five-in-one education mode focuses on a series of teaching researches and practices related to the cultivation plan, theoretical teaching, practical teaching, graduation project, and innovation and entrepreneurship $\operatorname{program}^{\text {(Fig. 1) }}$

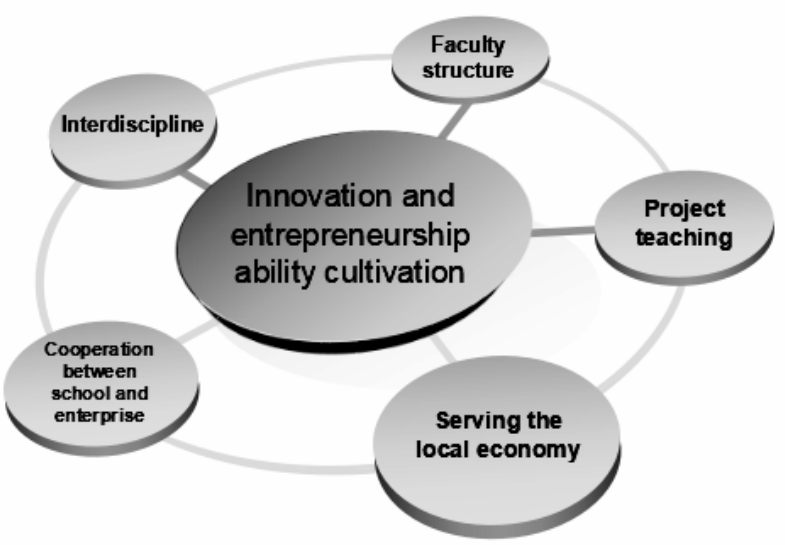

Figure 1. Five-in-one education system

\subsection{The all-around and multi-angle integration of disciplines and majors}

In order to strengthen students' practical ability and enable them put what they have learned into reality, the school has taken measures relevant to the design studio through all resources such as the establishment of textile design studio, ceramics design studio, and image design studio. When led by teachers to experience the real design project, students have the chance to witness the entire design process, master the whole procedure, and possess the precious work experience, thus making significant effects on the future study and work. In the 
other hand, it is also conducive to the profound exchanges and communications between teachers and students, and then promotes students' learning efficiency in the specialized courses of science and engineering. (Fig. 2)

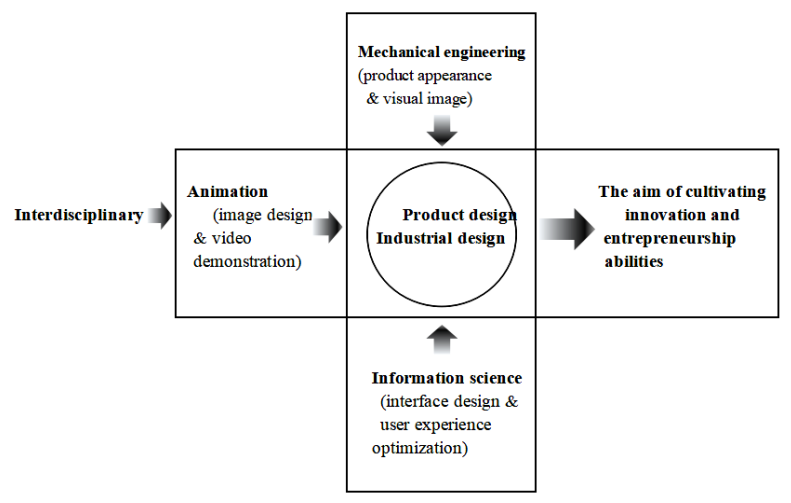

Figure 2. Integration of disciplines and majors

\subsection{The construction of faculty structure}

The four-year practical teaching requires cooperation of teachers between basic courses and specialized courses. Hence, the school has set up a teaching research team consisting of teachers of the basic courses and the specialized courses, gradually fostered its faculties, and employed experts from enterprises as teachers and instructors to improve students' innovation and entrepreneurship abilities.

\subsection{The introduction of project teaching to the curriculum system}

Attempts are made to productize the masterpieces shaped in the vocational teaching and research. At present under the influence of the Internet, it is improper to continue the traditional path from product design, lot production, and channel development to marketing. In the other hands, in order to realize design innovation, colleges and universities should construct a interdisciplinary mechanism with collaborative innovation, and transform the technical innovation into students' entrepreneurship; meantime, multiple factors such as the company's management mechanism and capital operation mechanism can be used together for high efficiency.

\subsection{The realization of the further cooperation between school and enterprise}

The five-in-one education system emphasizes the connections to the related domains in society; both direct employment and self-employment are available. In the last academic year, students are arranged to work in the relevant companies as interns, and their learning conditions will be reported to the school timely, which enables them to put the knowledge they have acquired in the class into practice. In addition, researches on the students' innovation and entrepreneurship projects are conducted. The school cultivate excellent graduates for those enterprises every year and allows priority selection of them. Taking advantage of the enterprises' technologies and equipment to co-share the resources of school and enterprise and combine with the training at class and social practice has not only extended the openness but also promoted the professionalization of the talent cultivation in design major and achieved deeper cooperation between schools and enterprise with mutual benefits.

\subsection{The service for the local economy}

As the talent training is able to facilitate the development of the local economy, a complete set of long-term and sustaining process must be formed in the marketization of technological achievements. Nowadays, almost no college and university has set up such a mechanism and applied it to the talent cultivation plan. Under such circumstances, enterprises get no information of the schools' projects, and the schools with innovated technologies cannot find the proper enterprises for cooperation either. Hence, barriers between the benefits of the local economy and the teaching and research should be broken in the ways of cultivation plan adjustment, theoretical teaching, practical training, graduation project, and innovation and entrepreneurship program.

\section{Five-in-one education system reform measures}

\subsection{Propelling innovation and entrepreneurship curriculum reform in design major}

With various forms such as entrepreneurship class, entrepreneurship training course, entrepreneurship imitation, and practical training of entrepreneurship activities, the students in design majors are taught with enterprise consciousness, entrepreneurship-related knowledge and skills to develop their potentials for entrepreneurship, enhance their abilities to capture, master, make use of, and create opportunities, and make a complete improvement in terms of the quality of the design talents of colleges and universities, thus more qualified entrepreneurs fostered and supplied with enterprising spirits and abilities for society. The practical teaching system with a purpose of developing students' innovation and entrepreneurship abilities should facilitate the new cultivation plan, reduce the credit in the theoretical teaching, and increase the practical credit. Generally, the education reform for the cultivation of innovation and entrepreneurship talents involves the following aspects. (Fig. 3) 


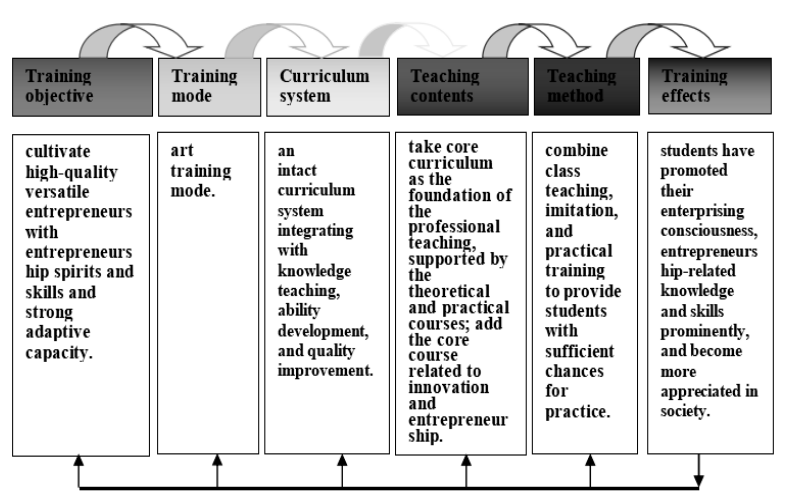

Figure 3. The framework of the education reform plan to train the talents with innovation and entrepreneurship abilities

\subsection{Strengthening the professional training course reform to adapt to innovation and entrepreneurship education}

In order to intensify innovation and entrepreneurship education, it is important to raise its status to that of the traditional professional training and the academic education. According to the education development trend, the reforms of the professional practical course assessment mode and the graduation project evaluation system are necessary. Four principles concerning the course assessment mode reform are to be followed, including the principle of diverse teaching modes, the principle of complete teaching contents, the principle of multiple evaluation subjects, the principle of instructive assessment results; besides, the reform should concentrate on the exploration of training objective, curriculum system, teaching mode, assessment mode, contents of examination, evaluation process, and information feedback. The practical teaching system based on innovation and entrepreneurship focuses on the cultivation of the five core abilities in design expression, design innovation, information analysis, team cooperation, and design practice.

\subsection{Course assessment mode reform}

\subsubsection{The final oral examination}

According to the cultivation plan, teachers make special choice of design and practical courses, and organize the final oral examination in the end of the course. The exam should be checked by the teacher of the course and other relevant professional teachers; they are to give scores and make comments in terms of students' whole oral defense of the homework. They will score rationally and fairly when referring to the evaluation standards and the comments of other teachers.

\subsubsection{Scoring collectively}

When the course comes to the end, the teaching and research group will organize teachers to score collectively; besides, the teacher of the course will also refer to the certain proportion of the evaluation standards.

\subsubsection{Analysis of the test paper}

In the beginning of every semester, the teaching and research group will also hold teaching discussions on the results of the test paper analysis, make conclusions on the problems existing in the teaching, analyze to what degrees the students has mastered the knowledge, and then adjust the teaching contents, teaching modes, and teaching methods to ensure the continuous improvement of teaching effect.

\subsection{4 summary of the course}

Summary is made to conclude the effects and experience of the teaching mode and method reforms on the basis of students' foundations, the aspects of reform with outstanding changes compared with the previous teaching, as well as the reference to the future teaching.

\subsection{Graduation project evaluation system reform}

To guarantee the quality of the thesis in the graduation project, the real-time management must be achieved in the whole process for the receiving of the latest feedback information. The evaluation and supervision is made from several aspects such as topic selection, sketch design, design scheme confirmation, early check, medium-term inspection, module making, and thesis defense; furthermore, following the graduation project, the work related to the conclusions and assessments of the graduation project also must be conducted to effectively perfect the graduates' design works. For the excellent designs in the graduation projects, teachers can instruct their owners to apply for patents, thus the teaching and research levels available to be promoted.

\section{Advantages of five-in-one education system reform}

The practical teaching system reform targeting the development of innovation and entrepreneurship abilities belongs to the next special practical link when the basic courses or the theoretical teaching of the specialized courses end. This teaching arrangement is good for students mastering the relevant knowledge and skills taught in the class. What's more, it breaks the traditional teaching mode, and structures a new mode integrating theoretical teaching, practical teaching, and innovation and entrepreneurship training.

First, the reform has established a set of scientific and feasible plan to cultivate talents with innovation and entrepreneurship abilities, thus meeting the current demands of the era when the economy of our country is developed based on the innovation-driven development strategy under the New Normal, comprehensive reforms 
are made in the higher education, and the high-quality employment is boosted by self-employment.

Second, the reform has formed a complete and appropriate innovation and entrepreneurship curriculum system, broken the traditional personnel training system, and enabled the innovation and entrepreneurship education geared to the needs of all the students in all the majors and every link of the entire study process. It abandons the barriers related to the conservative concepts, resources, and systems, and shaped a teaching vision aiming for education, concentrating on teaching, and relying on service, so that the teaching effects of students and teachers depending on each other and benefiting each other can be made.

Third, the reform has relieved the employment pressure of the graduates from the private colleges and universities, and also promoted their comprehensive competitive forces. Along with the increasing graduates and the decreasing positions offered by the traditional industries, the scientific and technological progress and the rising labor cost have invisibly reduced the employment space. The education and teaching reform is able to develop more talents with innovation and entrepreneurship abilities, so that the employment can be drive by entrepreneurship and the high-quality employment and enterprising are available for those graduates.

Fourth, the reform has built a mature and intact practical teaching platform, and extended the teaching out of the class, thus allowing teachers and students to touch the industry, society, and enterprise through various channels; the active participation in the practical projects enables students to closely link theory with practice and indeed achieve the practical teaching integrating education, practice, and entrepreneurship in the cooperation with the enterprises. The reform is to cultivate the excellent designers who can meet the social demands with high practical abilities, with an ultimate goal of realizing the effective transformation of technological achievements and serving the development and construction of the regional economy with the promoted competitiveness.

\section{Conclusion}

The ability-oriented innovation and entrepreneurship education system integrates five-in-one education system with teaching to benefit the local economy, and makes comprehensive reforms of the teaching in the design major of the private colleges and universities. Its training objectives of conducting project teaching, realizing further cooperation between school and enterprise, integrating different disciplines, constructing faculty structure, and serving the development of the local economy, is meaningful for the private applicationoriented colleges to foster the high-quality talents with innovation and entrepreneurship abilities through reform and practice.

\section{References}

1. Chen Jiangning, Innovation and Entrepreneurship Education: the Principal Line of Personnel Training System Construction in Colleges and Universities, Journal of Shangqiu Vocational and Technical College, 2012

2. https://wenku.baidu.com/view/f718fb0590c69ec3d5 bb75a0.html?edu_search=true (2010)

3. http://www.lunwentianxia.com/product.free.100732 $81.1 /(2014)$

4. Tian Hongxi \& Cao Shangqiu, Characteristics of the Mode Integrating with Art Teaching and Practice, Wenyi Zhengming (2010)

5. Liu Liqun, Establishing a Three-dimensional Practical Teaching System Conducive to the Cultivation of Students' Ability in Innovation and Entrepreneurship, Education and Occupation (2013)

6. Huang Benxiao \& Huang Hao, Literature Review on College Students' Innovation and Entrepreneurial Practice Platform Construction, Productivity Research (2014)

7. Chen Zhiwu \& Zhang Derong, Improve the Practical Teaching System, Train Applied Innovative Talents, Laboratory Research and Exploration (2012)

8. $\mathrm{Hu}$ Tao \& Shen Li, Enlightenment of Foreign Innovative and Entrepreneurial Education Models on Chinese Universities, Chinese University Teaching (2013) 